\title{
Faktor-Faktor yang Memengaruhi Keberhasilan Usaha UMKM Pengolahan Buah dan Pengolahan Susu
}

\author{
Factors Affecting Business Success of Fruit and Milk Processing \\ Bella Nandita ${ }^{1}$, Ma'mun Sarma $^{1 *}$, Mukhamad Najib $^{1}$ \\ ${ }^{1}$ Departemen Manajemen, Fakultas Ekonomi dan Manajemen, IPB Kampus Dramaga Bogor 16680
}

\begin{abstract}
Micro, small and medium enterprises are able to safe the economy, especially in Indonesia. On the other hand, Indonesia has to face the Asian Economic Community in 2025, that is why micro small and medium enterprises need to understand the factors of business success to compete in to participate in Asian Economic Community. The aims of this research are to know the business characteristics and businessmen characteristics of micro small and medium enterprises fruit and milk processing and to analyze factors affecting business success. Questionnaire surveys have been conducted to 31 respondents for each clusters, milk processing and fruit processing. Data were analyzed by descriptive and multiple linear regression analysis. Multiple linear regression has been conducted in order to examine the relative impact of the identified factors on business success. The factor that affecting business success in fruit and milk processing was entrepreneurial marketing and government policies. The results of this research can be beneficial to relevant agencies.
\end{abstract}

Keywords: business characteristic, business success, businessmen characteristic, entrepreneurial marketing, government policy

\section{ABSTRAK}

Usaha mikro kecil dan menengah (UMKM) mampu menyelamatkan perekonomian, terutama di Indonesia. Di sisi lain, tantangan bahwa Indonesia harus menghadapi Masyarakat Ekonomi Asean pada tahun 2025, maka dari itu UMKM perlu mengetahui faktor-faktor yang memengaruhi keberhsilan usaha dalam berpartisipasi pada Masyarakat Ekonomi Sean. Tujuan penelitian ini adalah untuk mengetahui karakteristik pelaku usaha, karakteristik usaha, dan factor-faktor yang memengaruhi keberhasilan usaha industri pengolahan buah dan pengolahan susu. Kuesioner yang dikumpulkan dalam penelitian sebanyak 31 dari masing-masing industri, yaitu pengolahan buah dan pengolahan susu. Data dianalisis menggunakan analisis deskriptif dan regresi linear berganda. Regresi linear berganda digunakan untuk menganalisis faktor-faktor yang signifikan memengaruhi keberhasilan usaha. Faktor-faktor yang memengaruhi secara signifikan keberhasilan usaha industri pengolahan buah dan susu adalah pemasaraan kewirausahaan dan kebijakan pemerintah. Hasil penelitian ini diharapkan dapat memberikan kontribusi bagi instansi terkait.

Kata Kunci: karakteristik usaha, karakteristik pelaku usaha, kebijakan pemerintah, pemasaran kewirausahaan

*Corresponding author

Alamat e-mail: mamun_sarma@yahoo.com 


\section{PENDAHULUAN}

Berdasarkan data Kementrian Koperasi, Usaha Kecil dan Menengah Republik Indonesia, pada tahun 2013 jumlah UMKM mencapai 57,89 juta unit usaha dan merupakan 99,99\% dari pelaku usaha nasional. Kontribusi UKM pada penyerapan tenaga kerja mencapai $97 \%$ dari penyerapan tenaga kerja yang ada (Kemenkop UKM 2014). Kemampuan UMKM juga mampu bertahan di tengah krisis yang terjadi pada tahun 1998, bahkan menyumbang hingga 57,56\% perekonomonian negara pada tahun 2013.

Dalam rangka pengembangan industri nasional sesuai dengan Pasal 2 Peraturan Presiden RI Nomor 20 Tahun 2008 tentang Kebijakan Industri Nasional, pengembangan kluster industri prioritas salah satunya mencakup industri berbasis agro. Industri Agro merupakan industri andalan masa depan, karena didukung oleh sumber daya alam yang cukup potensial yang berasal dari sektor pertanian, perikanan/kelautan, peternakan, perkebunan dan kehutanan (Kemenperin 2015).

Kontribusi klaster agro terhadap Produk Domestik Bruto (PDB) Nasional pada triwulan III tahun 2015 adalah 45,84\% meningkat sebesar 1,2\% dibanding triwulan III tahun 2014 yaitu sebesar $44,64 \%$. Industri makanan dan minuman merupakan penyumbang terhadap PDB terbesar pada sektor non migas dalam kurun waktu tahun 2011-2015, yaitu dengan rata-rata 5\% per tahun (Kemenperin 2016). Kemampuan UMKM dalam menyumbang terhadap PDB menunjukkan bahwa perhatian terhadap pengembangan UMKM, perlu dilakukan demi pertumbuhan ekonomi yang lebih baik (Indarti dan Marja 2004). Industri berbasis agro dikelompokkan menjadi klaster-klaster industri diantaranya adalah industri pengolahan susu dan industri pengolahan buah. Kedua klaster industri tersebut termasuk ke dalam kelompok prioritas industri agro yaitu industri pangan.

Nilai produksi industri pengolahan buah-buahan dan sayuran pada tahun 2013 senilai 469,1 miliar rupiah, produksi pengasinan dan pemanisan buah dan sayuran pada tahun 2014 senilai 133,8 miliar rupiah, industri pelumatan buah dan sayuran senilai 490,9 miliar rupiah, produksi pengeringan buah dan sayuran senilai 790,6 miliar rupiah, produksi pembekuan dan buah dan sayuran sebesar 472,4 miliar rupiah, produksi pengolahan dan pengawetan buah dan sayuran dalam kaleng sebesar 1,4 triliun rupiah (Kemenperin 2014). Nilai produksi yang dihasilkan masih dinilai kurang untuk memenuhi kebutuhan, hal ini ditunjukkan pada nilai impor buah dan sayuran yang dikeringkan pada tahun 2016 senilai USD 1,4 miliar, buah dan sayuran yang diawetkan USD 7,2 miliar, buah dan sayur yang dimaniskan USD 2,8 miliar, dan buah dan sayur yang dibekukan sebesar USD 31,9 juta (Kemenperin 2017).

Nilai produksi industri pengolahan susu dari susu dan eskrim pada tahun 2013 sebesar 4,1 miliar rupiah, pada tahun 2014 industri susu dari susu segar dan krim sebesar 1,95 trilyun rupiah, susu bubuk dan susu kental 11,7 triliun rupiah, dan produk dari susu lainnya sebesar 58,04 miliar rupiah (Kemenperin 2016). Jumlah tersebut tidak mencukupi kebutuhan, pemerintah melakukan impor pada tahun 2016 produk olahan susu kental sebesar USD 459, produk susu dan lainnya USD 349,7 miliar, eskrim USD 35,3 miliar, margarin USD 35,5 miliar, dan olahan susu segar dan krim USD 10,2 miliar.

Dalam rangka memaksimalkan potensi alam yang dimiliki dalam memproduksi olahan

buah dan susu, serta agar dapat memenuhi kebutuhan dalam negri UMKM Indonesia perlu mengetahui faktor-faktor keberhasilan usaha. Pengetahuan mengenai faktor-faktor yang memengaruhi keberhasilan usaha UMKM dapat menjadi pengetahuan bagi pelaku usaha agar mengetahui faktor apa saja yang mempengaruhi keberhasilan usaha secara signifikan. Pengetahuan mengenai faktor-faktor keberhasilan usaha juga dinilai sangat penting demi keberlanjutan dan perkembangan usaha agar dapat memberikan kontribusi bagi negara (Islam et al. 2011).

\section{METODE PENELITIAN}

Penelitian ini dilakukan di Kabupaten Bandung yang merupakan sentra industri pengolahan buah dan pengolahan susu. Lokasi penelitian industri pengolahan buah 
dilaksanakan di Kecamatan Ciwidey, Kabupaten Bandung, sedangkan lokasi penelitian industri pengolahahan susu dilakukan di Kecamatan Pangalengan, Kabupaten Bandung. Pemilihan industri dan sentra industri agro mengacu pada paparan dan penetapan oleh Kementerian Perindustrian Ditjen Agro. Waktu penelitian dilaksanakan pada bulan Mei - Juli 2017.

Jenis sumber data berupa data primer dan sekunder. Data primer diperoleh melalui observasi dan wawancara mendalam (in depth interview). Data sekunder diperoleh dari Penelitian Hibah Kompetensi Lembaga Penelitian dan Pengabdian Kepada Masyarakat Institut Pertanian Bogor dengan judul penelitian "Strategi Pemasaran UMKM Kluster Industri Berbasis Agro Dalam Menghadapi Masyarakat Ekonomi ASEAN (MEA)" (Sarma et al. 2016). Penelitian tersebut dibiayai oleh Direktorat Jendral Pendidikan Tinggi, dengan nomor kontrak No. Kontrak: 449/IT3/PN/2016.

Metode penarikan sampel yang digunakan dalam penelitian ini adalah purposive quota sampling, meliputi industri pengolahan buah (31 orang) dan industri pengolahan susu (31 orang). Jumlah responden yang diambil untuk penelitian ini adalah 62 orang yang mewakili UMKM unggulan di masing-masing industri.

Metode pengolahan data menggunakan deskriptif dan regresi linear berganda. Analisis deskriptif digunakan untuk menjabarkan karakteristik responden. Skala pengukuran pada kuesioner dilakukan dengan menggunakan skala Likert $1-4$. Regresi linear berganda dilakukan untuk mengidentifikasi variabel-variabel yang mempengaruhi keberhasilan usaha industri pengolahan buah dan pengolahan susu. Persamaan regresi linear berganda pada penelitian ini adalah sebagai berikut:

$$
\mathrm{Y}=\alpha+\beta_{1} \mathrm{X}_{1}+\beta_{2} \mathrm{X}_{2}+\beta_{3} \mathrm{X}_{3}+\beta_{4} \mathrm{X}_{4}+e
$$

Keterangan:

$\mathrm{Y}=$ Variabel keberhasilan usaha

$\mathrm{X}_{1}=$ Karakteristik pelaku usaha

$\mathrm{X}_{2}=$ Karakteristik usaha

$\mathrm{X}_{3}=$ Kebijakan pemerintah

$\mathrm{X}_{4}=$ Pemasaran kewirausahaan

$\alpha=$ Konstanta (Nilai $\mathrm{Y}$ apabila $\mathrm{X}_{1}, \mathrm{X}_{2}, \mathrm{X}_{3}, \mathrm{X}_{4}$ sama dengan 0)

$\beta=$ Koefisien regresi (nilai peningkatan atau penurunan)

Hipotesis penelitian merupakan jawaban sementara terhadap masalah penelitian dan dibuktikan melalui pengujian data yang terkumpul. Pengembangan hipotesis ini berdasarkan dari model penelitian maka hipotesis penelitian dirumuskan sebagai berikut:

H1o: Karakteristik pelaku usaha, karakteristik usaha, kebijakan pemerintah, dan pemasaran kewirausahaan secara bersama-sama tidak berpengaruh signifikan terhadap keberhasilan usaha industri pengolahan buah dan pengolahan susu.

$\mathrm{H}_{1}$ : Karakteristik pelaku usaha, karakteristik usaha, kebijakan pemerintah, dan pemasaran kewirausahaan secara bersama-sama berpengaruh signifikan terhadap keberhasilan usaha industri pengolahan buah dan pengolahan susu.

H2o: Karakteristik pelaku usaha, karakteristik usaha, kebijakan pemerintah, dan pemasaran kewirausahaan secara parsial tidak berpengaruh signifikan positif terhadap keberhasilan usaha industri pengolahan buah dan pengolahan susu.

$\mathrm{H} 2_{1}$ : Karakteristik pelaku usaha, karakteristik usaha, kebijakan pemerintah, dan pemasaran kewirausahaan secara parsial berpengaruh signifikan positif terhadap keberhasilan usaha industri pengolahan buah dan pengolahan susu.

\section{HASIL DAN PEMBAHASAN}

\section{Karakteristik Pelaku Usaha Industri Pengolahan Buah dan Pengolahan Susu}

Karakteristik pelaku usaha yang diteliti dalam penelitian ini terhadap UMKM industri pengolahan buah dan pengolahan susu adalah jenis kelamin, usia, pendidikan terakhir, pelatihan yang diikuti, dan alasan awal mula memulai usaha. Berdasarkan data yang diperoleh, kategori usia dibagi menjadi empat kategori usia, antara lain: $1=21-30$ tahun, $2=31-40$ tahun, $3=41-50$

Jurnal Manajemen dan Organisasi (JMO),

Vol. 9, No. 1, April 2018, Hal. 1-9 
tahun, dan $4=>50$ tahun. Pelaku usaha pada klaster pengolahan susu didominasi oleh kelompok usia $41-50$ tahun yaitu sebesar 52\%. Pelaku usaha pengolahan buah didominasi oleh kelompok usia 21 - 30 tahun.

Hal ini sesuai dengan observasi lapangan bahwa lebih mudah membuka usaha pengolahan buah dibanding dengan industri pengolahan lainnya. Alasan tersebut menjadi daya tarik pelaku usaha yang usianya lebih muda untuk menjalankankan usaha pada industri pengolahan buah. Data karakteristik pelaku usaha berdasarkan usia tersaji pada Tabel 1.

Tabel 1. Persentase karakteristik pelaku usaha berdasarkan usia

\begin{tabular}{ccc}
\hline Kategori Usia & Industri pengolahan Buah & Industri Pengolahan Susu \\
\hline $21-30$ tahun & $55 \%$ & $13 \%$ \\
$31-40$ tahun & $10 \%$ & $13 \%$ \\
$41-50$ tahun & $29 \%$ & $52 \%$ \\
$>50$ tahun & $6 \%$ & $23 \%$ \\
\hline
\end{tabular}

Berdasarkan hasil survey, pelaku usaha industri pengolahan buah didominasi oleh pelaku usaha berjenis kelamin perempuan, yaitu sebanyak 52\%. Hal ini dikarenakan pemilik usaha pengolahan buah mayoritas adalah seorang istri dari pemilik kebun buah, atau pekerja yang menggarap kebun buah. Tenaga pekerja perempuan dibutuhkan lebih banyak oleh pelaku usaha buah untuk pembagian pekerjaan pengemasan produk buah, seperti memotong dan membungkus dodol buah, selai buah, dan produk olahan buah lainnya. Pekerja perempuan dinilai lebih teliti dan rapi dalam mengemas makanan. Berbeda halnya dengan industri pengolahan susu yang didominasi dengan pelaku usaha berjenis kelamin laki-laki, yaitu sebanyak 58\%. Berdasarkan hasil observasi pelaku usaha industri pengolahan susu mayoritas adalah para pemilik sapi yang merupakan kepala keluarga. Data persentase karakteristik pelaku usaha berdasarkan jenis kelamin disajikan pada Tabel 2.

Tabel 2. Persentase karakteristik pelaku usaha berdasarkan jenis kelamin

\begin{tabular}{ccc}
\hline Jenis Kelamin & Industri Pengolahan Buah & Industri Pengolahan Susu \\
\hline Laki-laki & $45 \%$ & $58 \%$ \\
Perempuan & $52 \%$ & $42 \%$ \\
\hline
\end{tabular}

Latar belakang pendidikan para pelaku usaha industri pengolahan buah dan pengolahan susu didominasi oleh latar belakang pendidikan SMA/SMK/MA. Masing-masing persentasenya adalah $45 \%$ pelaku usaha industri pengolahan buah dan $49 \%$ pelaku usaha industri pengolahan susu. Berdasarkan observasi lapangan latar belakang pendidikan yang dimiliki para pelaku usaha UMKM menunjukkan bahwa para pelaku usaha dapat beradaptasi dengan perubahan pasar, terutama dalam hal pemanfaatan teknologi dalam hal pemasaran. Para pelaku usaha mengaku bahwa pendidikan diperlukan agar dapat mengelola usaha lebih baik, terutama dalam hal manajemen. Data persentase karakteristik pelaku usaha berdasarkan pendidikan terakhir disajikan pada Tabel 3 .

Jurnal Manajemen dan Organisasi (JMO),

Vol. 9, No. 1, April 2018, Hal. 1-9

Tabel 3. Persentase karakteristik pelaku usaha berdasarkan pendidikan terakhir

\begin{tabular}{ccc}
\hline Pendidikan Terakhir & Industri Pengolahan Buah & Industri Pengolahan Susu \\
\hline Tidak tamat sekolah & $0 \%$ & $3 \%$ \\
SD/MI & $13 \%$ & $3 \%$ \\
SMP Mts & $36 \%$ & $19 \%$ \\
SMA/SMK/MA & $45 \%$ & $49 \%$ \\
PT & $6 \%$ & $26 \%$ \\
\hline
\end{tabular}

Selain latar belakang pendidikan formal yang dimiliki, pelatihan-pelatihan yang diadakan oleh Dinas Koperasi dan Usaha Kecil Menengah merupakan ilmu yang dianggap bermanfaat dalam menjalankan usaha para pelaku usaha UMKM. Keikutsertaan pelaku usaha UMKM dalam berbagai pelatihan dikelompokkan dalam tiga kategori berdasarkan justifikasi peneliti, sebagai berikut: $1=<1$ hari, $2=1-2$ hari, dan $3=3-4$ hari. 
Berbagai informasi dan ilmu diperoleh dari pelatihan untuk mengembangkan usaha para pelaku UMKM. Manfaat lain dari pelatihan adalah pelaku usaha dapat bertemu dengan para pelaku usaha lain untuk saling memasarkan produk dan bertukar informasi. Namun hasil dari data yang terkumpul menunjukkan bahwa kedua industri pengolahan usaha industri pengolahan buah dan pengolahan susu mayoritas menghadiri pelatihan selama kurang dari satu hari dalam dua tahun. Hal ini dikarenakan para mayoritas pelaku usaha lebih memilih untuk menjalankan produksi usahanya. Berikut ini adalah Tabel 4 yang menunjukkan keikutsertaan pelaku usaha industri pengolahan buah dan pengolahan susu selama dua tahun.

Tabel 4. Persentase karakteristik pelaku usaha berdasarkan waktu pelatihan yang diikuti

\begin{tabular}{ccc}
\hline Kategori Waktu & Industri pengolahan Buah & Industri Pengolahan Susu \\
\hline$<1$ hari & $55 \%$ & $55 \%$ \\
$1-2$ hari & $35 \%$ & $32 \%$ \\
$3-4$ hari & $10 \%$ & $13 \%$ \\
\hline
\end{tabular}

Pada penelitian ini alasan awal mula berusaha pada bidang industri berbasis agro yaitu klaster pengolahan buah dan pengolahan susu dibagi menjadi empat yaitu keinginan sendiri, mengikuti jejak orang tua, diajak teman atau tetangga, dan tidak punya pilihan lain. Industri pengolahan buah dan pengolahan susu mayoritas memiliki alasan yang sama dalam mengawali usaha pada bidang tersebut yaitu karena keinginan sendiri. Pelaku usaha industri pengolahan buah yang mengawali usaha karena keinginan sendiri adalah sebanyak $81 \%$ dan $84 \%$ dari pelaku usaha industri pengolahan susu. Berdasarkan observasi lapangan alasan awal mula pelaku usaha melakukan usaha juga didukung oleh sumber daya alam yang tersedia di mana tempat mereka tinggal. Data lengkap alasan kedua industri dalam mengawali usaha tersaji pada Tabel 5.

Tabel 5. Persentase Karakteristik Pelaku Usaha berdasarkan Alasan awal memulai usaha

\begin{tabular}{ccc}
\hline Alasan Awal & Industri Pengolahan Buah & Industri Pengolahan Susu \\
\hline Keinginan sendiri & $81 \%$ & $84 \%$ \\
Mengikuti jejak orang tua & $13 \%$ & $16 \%$ \\
Diajak teman atau tetangga & $6 \%$ & $0 \%$ \\
Tidak punya pilihan lain & $0 \%$ & $0 \%$ \\
\hline
\end{tabular}

\section{Karakteristik Usaha Industri Pengolahan Buah dan Pengolahan Susu}

Karakteristik usaha yang diteliti pada penelitian ini terhadap industri pengolahan buah dan pengolahan susu dibedakan berdasarkan lama usaha, jenis usaha, omzet rata-rata per bulan, dan ketersediaan modal bagi para pengusaha kecil. Pelaku usaha pada industri pengolahan buah mayoritas telah menjalankan usahanya kurang dari lima tahun yaitu sebanyak $42 \%$, hal ini berkaitan dengan banyaknya muncul para pelaku usaha yang terbilang muda yang baru memulai usaha pada bidang pengolahan buah. Berbeda dengan industri pengolahan susu, mayoritas usahanya telah berjalan selama lima sampai sepuluh tahun yaitu sebanyak 58\%. Data menunjukkan bahwa pelaku usaha industri pengolahan susu lebih banyak yang dapat bertahan lebih lama dalam menjalankan usahanya. Tabel 6 menyajikan data secara lengkap.

Tabel 6. Persentase Karakteristik Usaha Berdasarkan Lama Usaha

\begin{tabular}{ccc}
\hline Lama Usaha & Industri Pengolahan Buah & Industri Pengolahan Susu \\
\hline$<5$ tahun & $42 \%$ & $23 \%$ \\
$5-10$ tahun & $35 \%$ & $58 \%$ \\
$>10$ tahun & $23 \%$ & $19 \%$ \\
\hline
\end{tabular}

Jurnal Manajemen dan Organisasi (JMO),

Vol. 9, No. 1, April 2018, Hal. 1-9

Industri pengolahan buah dan pengolahan susu mayoritas adalah usaha rumah tangga dengan jumlah pekerja 1-4 orang. Secara berurutan yaitu sebesar $81 \%$ dari industri pengolahan buah dan $74 \%$ industri pengolahan susu. Data lengkap disajikan pada Tabel 7. 
Tabel 7. Persentase Karakteristik Usaha Berdasarkan Jenis Usaha

\begin{tabular}{ccc}
\hline Jenis Usaha & Industri Pengolahan Buah & Industri Pengolahan \\
& Susu \\
\hline Industri rumah tangga (pekerja 1-4 orang) & $81 \%$ & $74 \%$ \\
$\begin{array}{c}\text { Industri kecil } \\
\text { (pekerja 5-19 orang) } \\
\begin{array}{c}\text { Industri sedang } \\
\text { (pekerja 20-99 orang) }\end{array}\end{array}$ & $16 \%$ & $19 \%$ \\
\hline
\end{tabular}

Data menunjukkan bahwa kedua industri pengolahan buah dan pengolahan susu mayoritas memiliki omzet sebanyak Rp. 1.000.000,- - Rp. 10.000.000,-. Data ini menunjukkan bahwa sebagian besar pelaku UMKM merupakan usaha mikro yang memiliki omzet kurang dari Rp. 25.000.000,- (UU No.20 Tahun 2008). Tabel 8 menyajikan data lengkap persentase karakteristik usaha berdasarkan omzet per bulan.

Tabel 8. Persentase karakteristik berdasarkan omzet rata-rata per bulan

\begin{tabular}{ccc}
\hline Omzet rata-rata per bulan & Industri Pengolahan Buah & Industri Pengolahan Susu \\
\hline$<$ Rp. 1000.000,- & $10 \%$ & $3 \%$ \\
Rp.1.000.000,- -Rp.10.000.000,- & $65 \%$ & $48 \%$ \\
Rp. 10.100.000,- -Rp.20.000.000,- & $16 \%$ & $10 \%$ \\
$>$ Rp.20.000.000,- & $10 \%$ & $39 \%$ \\
\hline
\end{tabular}

Para pelaku UMKM dalam memulai usaha memiliki kapasitas modal yang berbeda-beda. Diantara kedua industri, pengolahan buah dan pengolahan susu modal yang dimiliki mayoritas kurang memadai. Sebesar $74 \%$ pelaku usaha industri pengolahan buah memiliki modal kurang memadai, begitu pula dengan industri pengolahan susu yaitu sebesar 58\%. Berikut ini adalah Tabel 9 yang menyajikan data kepemilikan modal bagi pelaku usaha industri pengolahan buah dan pengolahan susu.

Tabel 9. Persentase kepemilikan modal pelaku usaha

\begin{tabular}{ccc}
\hline Kategori Kepemilikan Modal & Industri pengolahan buah & Industri pengolahan susu \\
\hline Sangat kurang memadai & $13 \%$ & $23 \%$ \\
Kurang memadai & $74 \%$ & $19 \%$ \\
Memadai & $13 \%$ & $58 \%$ \\
Sangat memadai & $0 \%$ & $0 \%$ \\
\hline
\end{tabular}

\section{Uji F dan Uji T}

Uji $\mathrm{F}$ dilakukan untuk mengetahui pengaruh secara bersama-sama variabel-variabel

Jurnal Manajemen dan Organisasi (JMO),

Vol. 9, No. 1, April 2018, Hal. 1-9 independen terhadap variabel dependen dengan nilai signifikansi kurang dari 0,005. Uji $\mathrm{T}$ dilakukan untuk mengetahui seberapa jauh pengaruh variabel indenenden secara parsial dalam menerangkan variasi variabel dependen. Model regresi linear berganda pada penelitian ini untuk mengetahui pengaruh karakteristik pelaku usaha (X1), karakteristik usaha (X2), kebijakan pemerintah (X3), dan pemasaran kewirausahaan (X4) terhadap Keberhasilan (Y).

Setelah melakukan uji validitas dilakukan uji $\mathrm{F}$ dan uji $\mathrm{T}$. Hasil uji $\mathrm{F}$ atau secara bersama-sama menunjukkan keempat variabel $\mathrm{X}$ yang digunakan dalam penelitian ini, yaitu karakteristik pelaku usaha, karakteristik usaha, kebijakan pemerintah, dan pemasaran kewirausahaan menunjukkan nilai signifikansi 0,000 . Nilai signifikansi yang dihasilkan diartikan bahwa keempat variabel tersebut signifikan terhadap keberhasilan usaha industri pengolahan buah dan susu karena kurang dari 0,005. Hasil uji F disajikan pada Tabel 10. 
Tabel 10. Hasil Uji F

\begin{tabular}{|c|c|c|c|c|c|}
\hline \multicolumn{6}{|c|}{ ANOVA } \\
\hline Model & Sum of Squares & Df & Mean Square & $\mathrm{F}$ & Sig. \\
\hline Regression & 10,891 & 4 & 2,723 & 19,532 &, $000^{b}$ \\
\hline Residual & 7,249 & 52 & 139 & & \\
\hline Total & 18,140 & 56 & & & \\
\hline
\end{tabular}

a. Dependent Variable: KEB

b. Predictors: (Constant), PK, KU, KPU, KP

Hasil uji $\mathrm{T}$ atau secara parsial besarnya pengaruh variabel pemasaran kewirausahaan dan kebijakan pemerintah ditunjukkan oleh nilai koefisien pada Tabel 11. Pemasaran kewirausahaan (PK) ditunjukan dengan nilai koefisien 0,295, lebih besar dibandingkan dengan nilai koefisien pada variabel kebijakan pemerintah (KP) sebesar 0,205. Nilai persamaan regresi linear berdasarkan Hasil uji T adalah:

$$
\mathrm{Y}=2,248+0,205 \mathrm{X}_{3}+0,295 \mathrm{X}_{4}+e \ldots(1)
$$

Faktor pertama yang terbukti berpengaruh signifikan positif terhadap keberhasilan usaha adalah Kebijakan pemerintah. Hal ini dikarenakan mayoritas pelaku usaha memanfaatkan kemudahan meminjam modal dan berpartisipasi dalam pelatihan-pelatihan yang diselenggarakan oleh pemerintah kabupaten, dalam hal ini Dinas Perdagangan dan Perindustrian Kabupaten Bandung. Pelatihan yang diselenggarakan oleh Dinas Perdagangan dan Perindustrian meliputi pelatihan pengelolaan usaha, pelatihan pemasaran dan penjualan, pelatihan pengolahan produk, dan pelatihan keuangan. Hasil ini tidak sejalan dengan penelitian yang dilakukan oleh Indiarti dan Marja (2004) yang menyatakan bahwa government support tidak memiliki pengaruh terhadap keberhasilan usaha.

Faktor kedua yang berpengaruh signifikan positif terhadap keberhasilan usaha adalah pemasaran kewirausahaan. Berdasarkan observasi dan wawancara, pelaku usaha melakukan pemasaran produk dengan cara memanfaatkan jaringan dengan sesama pelaku usaha, informasi dari mulut ke mulut, dan menyesuaikan selera pasar. Hasil penelitian ini sejalan dengan hasil penelitan yang dilakukan oleh Resnick et al. (2011) yang menyatakan bahwa fokus dari pemasaran usaha kecil menengah adalah keterlibatan pelanggan, jaringan, dan informasi mulut ke mulut. Obervasi dan wawancara kepada pelaku usaha juga menghasilkan bahwa pelaku usaha yang aktif dalam memasarkan produknya, dan fleksibel terhadap perubahan baik dari penyesuaian selera pasar, kemasan, maupun cara memasarkan produk, dan memiliki jaringan yang luas memiliki usaha yang lebih baik dibanding pelaku usaha yang tidak fleksibel terhadap perubahan. Perubahan yang dimaksud adalah penyesuaian selera pasar yang dinamis, kemasan, dan distribusi pemasarannya. Berani berinovasi dalam menciptakan variasi produk juga menjadi salah satu alasan pelaku usaha menjalankan usahanya lebih baik, hal ini sejalan dengan penelitian yang dilakukan oleh Islam et al. (2011) yang menyatakan produk yang inovatif merupakan salah satu kunci strategi keberhasilan usaha dan fleksibilitas memainkan peranan penting dalam keberhasilan usaha. Hasil uji T disajikan pada Tabel 11.

Tabel 11. Hasil Uji T

\begin{tabular}{|c|c|c|c|c|c|c|}
\hline \multicolumn{7}{|c|}{ Coefficients $^{\mathrm{a}}$} \\
\hline \multirow[b]{2}{*}{ Model } & & \multicolumn{2}{|c|}{ Unstandardized Coefficients } & \multirow{2}{*}{$\begin{array}{c}\begin{array}{r}\text { Standardized } \\
\text { Coefficients }\end{array} \\
\text { Beta }\end{array}$} & \multirow[b]{2}{*}{$\mathrm{T}$} & \multirow[b]{2}{*}{ Sig. } \\
\hline & & $\mathrm{B}$ & Std. Error & & & \\
\hline \multirow[t]{5}{*}{1} & (Constant) & 2,248 & 266 & & 8,436 &, 000 \\
\hline & KPU &,- 120 & ,089 &,- 124 & $-1,354$ & , 182 \\
\hline & KU &,- 057 & ,089 &,- 056 &,- 641 &, 524 \\
\hline & KP & ,205 & ,091 &, 292 & 2,244 & 029 \\
\hline & PK & ,295 & ,080 & ,496 & 3,691 & ,001 \\
\hline
\end{tabular}

Jurnal Manajemen dan Organisasi (JMO),

Vol. 9, No. 1, April 2018, Hal. 1-9

a. Dependent Variable: KEB 
Variabel Keberhasilan usaha (Y) dapat dijelaskan oleh variabel karakteristik pelaku usaha, karakteristik usaha, pemasaran kewirausahaan dan kebijakan pemerintah yang ditunjukkan pada nilai Adjusted $R$ Square. Tabel 12 menyajikan nilai Adjusted $R$ square sebesar 0,570. Hal ini dapat diartikan bahwa keempat variabel yang diteliti di dalam penelitian ini menjelaskan keberhasilan usaha industri pengolahan buah dan pengolahan susu sebesar 57\%, sebesar $43 \%$ lainnya dijelaskan oleh variabel lain yang tidak diteliti dalam penelitian ini.

Tabel 12. Model Summary

\begin{tabular}{ccccc}
\hline Model & $\mathrm{R}$ & $\mathrm{R}$ Square & $\begin{array}{r}\text { Model Summary } \\
\text { Adjusted R Square }\end{array}$ & Std. Error of the Estimate \\
\hline 1 &, $775^{\mathrm{a}}$ &, 600 &, 570 &, 37337 \\
\hline
\end{tabular}

a. Predictors: (Constant), PK, KU, KPU, KP

\section{KESIMPULAN}

Berdasarkan pembahasan yang telah dipaparkan, kesimpulan yang diambil dari hasil penelitian ini adalah Karakteristik pelaku usaha industri pengolahan susu dan pengolahan buah yaitu: (a) industri pengolahan buah didominasi oleh kategori usia 21-30 tahun sebesar 55\%, jenis kelamin mayoritas pelaku usaha perempuan sebesar $52 \%$, pendidikan terakhir SMA/SMK/MA sebesar 45\%, pelatihan yang diikuti kurang dari satu hari sebesar 55\%, dan alasan memulai usaha karena keinginan sendiri sebesar $81 \%$ (b) industri pengolahan susu didominasi oleh: kategori usia 41-50 tahun sebesar 52\%, pelaku usaha berjenis kelamin laki-laki sebesar 58\%, pendidikan terakhir SMA/SMK/MA sebesar 49\%, mengikuti pelatihan kurang dari satu hari sebesar $55 \%$, dan memulai usaha karena keinginan sendiri sebesar $84 \%$.

Karakteristik usaha industri pengolahan buah didominasi oleh usaha yang lama usahanya kurang dari lima tahun sebesar $42 \%$, industri rumah tangga dengan jumlah pekerja 1-4 orang sebesar $81 \%$, memiliki omzet rata-rata Rp. 1.000 .000 ,- - Rp. 10.000.000,- per bulan sebesar $65 \%$, dan kepemilikan modal usaha kurang memadai sebesar $74 \%$. Sedangkan industri pengolahan susu yang didominasi oleh 58\% dengan lama usaha 5-10\%, 74\% merupakan industri rumah tangga, 48\% memiliki omzet rata-rata per bulan sebesar Rp. 1.000.000,- - Rp. 10.000.000,- dan sebesar 58\% dengan kepemilikian modal usaha yang memadai.

Hasil penelitian menunjukkan bahwa karakteristik pelaku usaha, karakteristik usaha, kebijakan pemerintah dan pemasaran kewirausahaan secara bersama-sama memiliki pengaruh yang signifikan terhadap keberhasilan usaha. Secara parsial kebijakan pemerintah dan pemasaran kewirausahaan berpengaruh positif dan signifikan terhadap keberhasilan usaha.

Jurnal Manajemen dan Organisasi (JMO),

Vol. 9, No. 1, April 2018, Hal. 1-9

\section{DAFTAR PUSTAKA}

Indiarti N, Maria L. 2004. Factors Affecting Business Success among SMEs: Empirical Evidences from Indonesia. Journal of Asia Entrepreneurship and Sustainability. 3(2).

Islam MA, Thiyada K, Dayang H, Muhamad Y. 2011. Factors Affecting Business Success of Small \& Medium Enterprises (SMEs) in Thailand. Asian Social Science. 7(5):180-190.

[Kemenperin] Kementerian Perindustrian Republik Indonesia. 2009. Peta Panduan Pengembangan Klaster Industri Prioritas Industri Berbasis Agro 2010-2014. [internet]. [diunduh 2016 Juli 14]. Tersedia pada agro.kemenperin.go.id/media/download/582.

[Kemenkop UKM] Kementerian Koperasi dan Usaha Kecil dan Menengah Republik Indonesia. 2014. Perkembangan Data Usaha Mikro, Kecil, Menengah (UMKM) dan Usaha Besar (UB) Tahun 2012-2013 [internet]. [diunduh 2016 Agustus 24]. Tersedia pada:http://www.depkop.go.id/pdfviewer/?p=uploads/tx_rtgfiles/sandingan_data_umkm_ 2012-2013.pdf.

[Kemenperin] Kementerian Perindustrian Republik Indonesia. 2016a. Kontribusi Pengolahan Non Migas Terhadap PDB. [internet]. [diunduh 2016 Agustus 24]. Tersedia pada: 
http://www.kemenperin.go.id/artikel/14200/KontribusiUM KM-Naik.

[Kemenperin] Kementerian Perindustrian Republik Indonesia. 2016b. Data Industri Pengolahan Susu Periode 2010-2014 [internet]. [diunduh 2018 Januari 1]. Tersedia pada: http://kemenperin.go.id/statistik/subsektor.php? kode=202010\&ekspor=.

[Kemenperin] Kementerian Perindustrian Republik Indonesia. 2016c. Kinerja Industri 20102014 [internet]. [diunduh 2018 Januari 1]. Tersedia pada: http://kemenperin.go.id/statistik/subsektor.php?kode= 202010\&ekspor=.

[Kemenperin] Kementerian Perindustrian Republik Indonesia. 2017. Perkembangan Impor Kelompok Industri Makanan. [internet]. [diunduh 2018 Januari 2]. Tersedia pada: http://kemenperin.go.id/statistik/subsektor.php? kode=202010\&ekspor=.

Resnick S, Ranis C, Clare B, Carley F. 2011. Aligning Teaching and Practice: a study of SME marketing. Journal of Research in Marketing and Entrepreneurship. 13(1):37-46.

Sarma M, Herien P, Siregar EH. 2016. Strategi Pemasaran UMKM Industri Berbasis Agro Dalam Menghadapi Masyarakat Ekonomi ASEAN (MEA) Dengan Pendekatan Entrepreuneurial Marketing. Makalah Seminar. 